\section{Planejamento urbano e política habitacional no Brasil: institucionalização, dicotomização, municipalização. Reflexões a partir do caso de São Carlos - SP}

\section{Thaís Troncon Rosa}

Arquiteta e urbanista, doutoranda em Arquitetura e Urbanismo pelo Instituto de Arquitetura e Urbanismo - USP, pesquisadora do Laboratório de Estudos do Ambiente Urbano Contemporâneo LEAUC/IAU-USP, Av. Trabalhador São-Carlense, 400, 13566-590, São Carlos, SP, (16) 9116-9250, thaisrosa@yahoo.com

\begin{abstract}
Resumo
O artigo toma como ponto de partida o ápice do processo de institucionalização do planejamento urbano no Brasil (constituição SERFHAU e BNH), acompanhando a dicotomização da política urbana federal nesse contexto, a emergência de empresas mistas como agentes operadores de tal política, até sua completa fragmentação, resultando em uma municipalização compulsória dos processos de planejamento e das políticas urbanas e habitacionais. Visando a apreender tais processos na escala do município, procede a um estudo de caso, analisando historicamente a constituição da empresa mista PROHAB, em São Carlos/SP, e perscrutando suas conexões com o contexto mais amplo das políticas urbanas e habitacionais no país.
\end{abstract}

Palavras-chave: planejamento urbano, política habitacional, São Carlos-SP guarda permanências em relação a esse processo, em especial referentes à construção da "concepção de planejamento como função de governo", a qual se evidenciará, ganhando escala federal, com a criação do SERFHAU, em 1964. Outros aspectos parecem apontar, também, para tal perspectiva de continuidade (ainda que não de linearidade) ao longo desse ciclo de quatro décadas, como: o planejamento entendido como técnica de administração; a associação entre planejamento e desenvolvimento; a incorporação da totalidade do território urbano nacional como objeto de atuação dos urbanistas (não apenas as cidades capitais); a intenção de fortalecimento do município e suas instituições como lócus privilegiado de planejamento urbano (focalizando em ações de assistência técnica); a reivindicação acerca da formulação de uma política nacional que articulasse habitação e urbanismo, para citar alguns dos denominadores comuns que vieram se construindo e/ou consolidando no referido 
1 Cf. Bolaffi (1982). Ressalte-se aqui, também, a importância adquirida pela "questão da casa própria", em um contexto em que se fazia premente, ao governo, a adoção de instrumentos de controle social e econômico frente à combinação entre crescimento das cidades e ausência de infraestrutura, moradia e trabalho.

2 Vale lembrar que no ano anterior havia ocorrido o Seminário de Habitação e Reforma Urbana, organizado pelo IAB, cujo objetivo maior foi justamente debater e definir as bases de uma política nacional de habitação e planejamento urbano e teve, como uma de suas propostas, a criação de um órgão federal nesse sentido (Mota, 2004).

${ }^{3}$ Cf. Lei Federal 4380/64.

4 Configura-se, nesse momento, o Sistema Nacional de Planejamento do Desenvolvimento Local Integrado, o qual seria formado pelos órgãos e entidades regionais, estaduais e municipais que desenvolvessem os planos integrados (Mota, 2004:64).

5 Esse modelo de política e financiamento público é, desde então, a base da atuação de grande parte dos governos municipais frente às questões habitacionais $\mathrm{e}$ urbanas, como veremos no caso estudado. período (Feldman, 2005; Motta, 2004). De fato, em tese, todos esses aspectos estariam no horizonte ao menos discursivo - da criação do SERFHAU e do Banco Nacional da Habitação - BNH.

No início da década de 1960, a população urbana do país representava $45,08 \%$ da população total: o processo de urbanização e industrialização e o crescimento metropolitano eram intensos, e os problemas deles decorrentes se tornavam cada vez mais agudos e evidentes, tais como a ampliação de favelas e a abertura de loteamentos periféricos (muitas vezes clandestinos) em diversas capitais, expressões do acelerado crescimento da demanda por habitação urbana e da incapacidade das cidades em atender a população com adequadas infraestrutura, moradia e trabalho (Monte-Mór 2008, Bonduki, 1998). Posicionando-se frente a esse contexto (muito em função da necessidade de formular projetos capazes de conservar o apoio das massas populares¹), o governo militar irá instituir, já em seu primeiro ano, os órgãos SERFHAU e BNH ${ }^{2}$ (bem como o Sistema Financeiro da Habitação - SFH), tendo a modernização das estruturas urbanas e a execução de um plano habitacional como metas de âmbito federal, vinculadas diretamente às diretrizes de desenvolvimento econômico do país.

Primeiro órgão federal voltado ao planejamento urbano, vinculado ao Ministério do Interior, o SERFHAU originalmente teria uma ampla atuação frente a questões ligadas tanto à habitação (tendo absorvido os processos da Fundação da Casa Popular, como seu órgão sucedâneo) quanto ao planejamento urbano $^{3}$, o que poderia ser interpretado como uma intenção de aproximar ambas as políticas sob a coordenação de um único órgão federal: centralizada no SERFHAU, uma política urbana federal parecia estar sendo gestada em articulação direta à questão habitacional, que estaria, mais especificamente, a cargo do BNH (órgão central do SFH). Nessa estrutura primeira, o BNH já seria, portanto, um elemento fundamental da política urbana, mas subordinado às diretrizes mais amplas estabelecidas pelo SERFHAU.

Entretanto, conforme destaca Monte-Mór (2008:47), embora tais medidas institucionais caminhassem rumo a uma maior integração da atuação do Estado face aos problemas urbanos, no sentido de construção de uma política urbana nacional, o que ocorreu efetivamente foi uma "verdadeira dicotomia nas ações governamentais". De fato, ainda que em um primeiro momento o SERFHAU fosse responsável - ao menos em tese - pela articulação entre as políticas urbanas e habitacionais, já quando de sua efetiva regulamentação (decreto 59917/66) as funções do órgão seriam direcionadas mais especificamente ao planejamento local integrado4, ganhando força um viés de assistência técnica aos municípios e minimizando aquela perspectiva de atuação articuladora frente à temática habitacional. Já em 1967, muito embora o Plano Decenal ainda estabelecesse discursivamente diretrizes para o que poderia vir a ser uma política urbana nacional - enfocando desde os problemas intraurbanos em curso no país até questões relativas à rede urbana nacional, ao papel dos municípios e à necessidade de modernização de suas administrações, para citar alguns aspectos -, o SERFHAU e o BNH tomariam caminhos completamente distintos frente ao desenvolvimento urbano do país (Monte-Mór, 2008).

Na prática, a partir de sua regulamentação, o SERFHAU teria sua atuação oficialmente subordinada ao BNH, através de uma estrutura administrativa que vinculava a aprovação de sua programação anual, bem como a escolha de seu Superintendente e de sua Comissão Consultiva ao Conselho de Administração e à Diretoria do BNH (Mota, 2004). Teria início, nesse momento, o processo de sobreposição do BNH ao SERFHAU frente ao encaminhamento de uma política urbana no país, que acabaria por culminar na extinção deste último, ficando definitivamente tal política nas mãos do Banco a partir de 1975.

\section{A política urbana federal dicotomizada: SERFHAU e BNH}

De modo geral, o funcionamento do sistema SERFHAU - BNH alinhava-se, desde sua concepção, às políticas públicas promovidas pelo Estado brasileiro no regime militar, caracterizadas pela centralização decisória e financeira na esfera federal: aos estados e municípios caberia tão somente a função de execução das políticas formuladas na esfera central, de modo que as instâncias governamentais, nas esferas estadual e municipal, acabavam se tornando meras agenciadoras de recursos federais ${ }^{5}$, atendendo às exigências da política centralizada para obtê-los (Heck, 2004). 
${ }^{6}$ Constituído quando da regulamentação do SERFHAU, seus recursos provinham, basicamente, do BNH.

7 Desde pelo menos a década de 1950, grupos de arquitetos, através do IAB, estabeleceram discussões, reivindicações e projetos de lei voltados à questão do financiamento para a elaboração e execução de planos diretores (Mota, 2004).

8 Também denominados, em esfera municipal, Planos Diretores de Desenvolvimento Integrado-PDDI.

9 Ferreira (2007:186), após estudo minucioso sobre o processo de construção e implementação do PDDI de Franca, questiona tais abordagens, ao mapear que nas cidades de menor porte esta realidade teria sido diferente. Também o estudo de Lima (2007) sobre o caso de São Carlos traz questões semeIhantes.
No caso específico do SERFHAU, a concepção de um "sistema nacional de planejamento" articulado a um fundo específico de financiamento pode ser analisada sob dois enfoques: por um lado, a criação do Fundo de Financiamento de Planos de Desenvolvimento Local Integrado (FIPLAN) ${ }^{6}$, além de atender a reivindicações históricas dos arquitetos $^{7}$, foi uma conquista inegável no processo de institucionalização do planejamento no país, funcionando como estímulo e viabilizando assistência técnica à elaboração de planos e efetivação de órgãos de planejamento pelos municípios; por outro, seu funcionamento, ao condicionar a liberação de recursos à existência dos planos, à criação de órgãos de planejamento e desenvolvimento local permanentes e à aceitação da assistência técnica que o SERFHAU julgasse necessária a tais órgãos, alinhava-se estritamente ao caráter centralizador do regime militar, operando, de certa forma, como instrumento de tutela da esfera de poder municipal (Mota, 2004; Feldman, 2005; Ferreira, 2007).

Conforme aponta Monte-Mór (2008): “montou-se todo um discurso de planejamento urbano voltado para o fortalecimento da célula mínima autônoma da nação - o município - quando os instrumentos da política eram cada vez mais centralizados e autoritários". Assim, tendo na assistência técnica aos municípios sua atuação mais eloquente e vendo, paulatinamente, seus propósitos iniciais cada vez mais dissonantes em relação às posturas do $\mathrm{BNH}$ e às estratégias de desenvolvimento econômico estabelecidas para o país, em termos concretos, o SERFHAU acabou por limitar-se a um órgão de assistência técnica já em 1970, tendo eliminadas suas funções coordenadoras mais amplas e bastante reduzidas suas atribuições quanto ao planejamento urbano propriamente dito (Feldman, 2005; Ferreira, 2007).

Nesse sentido, ao passo em que reforçava a centralização administrativa e financeira, o SERFHAU, ao incentivar a elaboração dos Planos de Desenvolvimento Local Integrado - PDLI (fornecendo, "didaticamente", uma espécie de "manual" para sua elaboração conforme as diretrizes formuladas centralmente), sob a perspectiva de proceder a uma "modernização induzida" das esferas de governo (em especial a municipal), irá acarretar uma descentralização institucional, ainda que dependente financeiramente. Muitos municípios terão, nesse contexto, a oportunidade de criar e efetivar estruturas locais de planejamento urbano, tendo a capacitação de suas equipes técnicas e a elaboração do Plano financiadas pelo Sistema.

Segundo Heck (2004), no estado de São Paulo, cerca de 154 equipes municipais foram capacitadas e 88 planos concluídos durante a vigência do SERFHAU e do FIPLAN. Ainda que a qualidade e a efetividade dos Planos desenvolvidos no período seja objeto de debates, sendo sua pouca operacionalidade ou sua pecha de "autoritários" e "tecnocráticos" (em uma associação imediata entre a instituição, os diversos planos através dela elaborados e o período político) constantemente acionadas, de forma generalizadora ${ }^{9}$, como fator desqualificador desse momento do planejamento urbano no Brasil (Feldman, 2005), é inevitável constatar a amplitude do processo de institucionalização do planejamento nesse período: sua incorporação definitiva nas estruturas municipais de inúmeras cidades no país, resultou, de forma diversa em cada caso, não apenas na elaboração de planos, mas também em reformas administrativas, na criação de órgãos de planejamento, em profissionais capacitados e em legislações urbanísticas atualizadas.

Obviamente, os resultados que podem ser extraídos desse momento de ápice da institucionalização do planejamento não são unívocos, assim como o próprio órgão não o era. Dentre os vários paradoxos, alguns já abordados anteriormente, valeria ressaltar, ainda, aquele que constitui justamente a particularidade do momento de criação do SERFHAU frente ao referido ciclo de institucionalização do planejamento urbano no país: a terceirização dos planos a "empresas de engenharia consultiva" (Feldman, 2005).

Nesse sentido, se, por um lado, o SERFHAU, enquanto primeiro órgão federal de planejamento urbano, reafirmaria o tripé que desde os anos 1930 estruturava os debates e atuações no campo do urbanismo no Brasil (plano diretor - órgãos de planejamento - assistência técnica aos municípios), por outro, ao possibilitar às prefeituras a contratação de empresas para a elaboração dos Planos, o próprio órgão, contraditoriamente, desestruturaria esse tripé e, com ele, todo o longo processo de construção da concepção de planejamento como função de governo. A incorporação das empresas de consultoria 
se vincularia ao interesse econômico despertado pelo "setor de desenvolvimento urbano", a partir dos recursos gerenciados pelo $\mathrm{BNH}$, e assinalaria o ápice de uma "concepção administrativa que tem como principal característica o divórcio entre a atividade técnica e a ação política e cotidiana da administração", e, consequentemente, da "tecnicização do urbanismo" em curso no país desde 1930 (Feldman, 2005:2,3,10).

Talvez esse fosse o principal ponto de conexão entre a atuação do SERFHAU e a do BNH: a inserção, cada vez mais crescente, de empresas de engenharia no referido "setor de desenvolvimento urbano", coadunando com as diretrizes de desenvolvimento econômico do regime militar. Atuando inicialmente com foco direcionado para a habitação, aos poucos o BNH passará a atuar de forma mais contundente nas mais diversas dimensões das políticas urbanas, incorporando decisivamente essa dimensão empresarial: "sua crescente atuação na provisão de infraestrutura urbana se dará diretamente através de órgãos públicos ou indiretamente através de um grande número de empresas privadas que gravitam em torno dos recursos que controla e movimenta" (Feldman, 2005:10). Na prática, justamente por deter o controle sobre os recursos, o BNH (sobrepondo-se ao SERFHAU) acabou por tomar para si a definição e a implementação concreta da política urbana no país (Azevedo, 2007).

\section{O BNH e os rumos da política urbana no país: empresas públicas e mistas como agentes operadores}

Considera-se importante ressaltar tal aspecto, pois, como já indicado anteriormente, a atuação do $\mathrm{BNH}$, desde o início, seguiria caminhos bastante distintos tanto em relação à atuação do SERFHAU, quanto às diretrizes do que poderia vir a ser uma política urbana nacional, expressas no referido Plano Decenal de 1967. Enquanto tais diretrizes e a própria atuação do SERFHAU, bem ou mal, apostavam no planejamento em nível municipal como estratégia de crescimento mais equilibrado e, até mesmo, de descentralização ${ }^{10}$, o BNH alinhava-se às estratégias de crescimento econômico estabelecidas pelo Ministério da Fazenda, as quais se apoiavam, ainda que implicitamente, em um modelo de concentração urbana, investindo prioritariamente nos principais centros urbanos.
Royer (2009) distingue quatro períodos distintos na atuação do Banco. O período inicial se configuraria pela estruturação institucional do BHN e do SFH, compreendendo a estruturação das Companhias de Habitação (COHABs) como agentes promotores públicos voltados ao atendimento da população de renda mais baixa (0-3 salários mínimos) e de agentes financeiros privados, os quais financiavam investimentos habitacionais propostos por empreendedores ou construtoras, destinados basicamente à população de renda média e alta. As COHABs configuravam-se como empresas mistas sob o controle acionário dos governos estaduais e/ ou municipais, responsáveis pela apresentação de projetos técnicos condicionados à aprovação do Banco para liberação de recursos, pela construção das unidades habitacionais e, também, pelas atividades financeiras referentes à comercialização das mesmas. Nesse momento, constitui-se um modelo de atuação governamental sobre a questão da hoje denominada habitação de interesse social que se perpetuará para além do período $\mathrm{BNH}$, como demonstrado adiante, no qual a figura da "empresa mista" como "agente operador" tornar-se-ia cada vez mais disseminada.

De fato, a constituição de empresas públicas e mistas se fará crescente no país a partir de 1967, quando se inicia a Reforma Administrativa. O decreto-lei 200/67, ao dispor sobre "a organização da Administração Federal", delineará duas frentes administrativas que passariam a constituí-la - a "Administração Direta" e a "Administração Indireta" (artigo 4). Dentre as figuras jurídicas compreendidas por esta última, são instituídas a empresa pública e a sociedade de economia mista como "novos instrumentos" para a viabilização de serviços públicos, cuja justificativa central seria possibilitar um maior grau de liberdade de atuação ao governo. Conforme destaca Heck (2004:91), tais figuras jurídicas se conformariam em mecanismo ideal para a gestão das políticas públicas do governo militar:

\section{(...) após 1968, no quadro político propiciado pelo} esvaziamento do Legislativo, ocorre uma centralização das decisões nas mãos do Poder Executivo e uma descentralização de execução das políticas propostas. Essa descentralização significou a multiplicação de unidades regionais - de responsabilidade dos estados e municípios - executoras de políticas deliberadas e coordenadas por unidades centrais, com consequente 
fortalecimento do poder central em detrimento dos governos estaduais e municipais.

Nesse sentido, o segundo período se iniciaria nos primeiros anos da década de 1970, tendo como marco justamente a transformação institucional do próprio BNH em empresa pública, em 1973. Sua característica central seria a significativa amplificação do escopo de atuação do órgão, que diversifica seus programas, passando a financiar obras urbanas, de modo a incorporar como tomadores de empréstimos não mais apenas as COHABs, mas também os estados, municípios e as diversas novas empresas públicas e mistas surgidas nesse período, além das empresas privadas mencionadas anteriormente.

Nesse momento, o BNH já se configurara como o "principal definidor da política urbana no Brasil" e, após onze anos de existência e atuação progressivamente limitadas, o SERFHAU é extinto em 1975. As questões urbanas e habitacionais, tal qual delineadas pelo $\mathrm{BNH}$, constituem-se definitivamente como cerne das políticas de desenvolvimento econômico do regime militar: a partir desse segundo período, - Banco passaria a exercer "papel determinante na promoção da indústria da construção civil e, portanto, do nível de atividade e emprego do país" (Santos, 1999:12). Seriam duas as frentes de programas desse período: uma primeira, que compreenderia os programas focalizados em grandes obras urbanas, e uma segunda, dos chamados "programas complementares", destinados a dotar de infraestrutura básica os próprios conjuntos financiados com recursos do BNH.

Esse será o contexto de florescimento de uma série de empresas públicas e mistas municipais, em especial nas grandes cidades e centros urbanos em rápido desenvolvimento: além de o modelo de administração por elas preconizado ser considerado inovador para as grandes cidades brasileiras (incorporando a lógica empresarial, a tecnificação mencionada anteriormente, também nas administrações municipais), tal disseminação vinculava-se, também, à perspectiva de obtenção de mais recursos para os estados e municípios, junto ao BNH, dadas as novas frentes de programas abertas nesse período (Heck, 2004:209). Foram, então, constituídas, por exemplo, a EMURB - Empresa Municipal de Urbanização de São Paulo (1971), a EMPLASA - Empresa Paulista de
Planejamento Metropolitano S.A. (1975), a URBES - Empresa de Desenvolvimento Urbano e Social de Sorocaba (1978 - originalmente denominada Companhia de Desenvolvimento de Sorocaba), a EMDURB - Empresa Municipal de Desenvolvimento Urbano e Rural de Bauru (1979), a EMDURB - Empresa Municipal de Desenvolvimento Urbano de Ubatuba (1979), para citar algumas.

Uma terceira fase compreenderia a retomada da atuação do Banco destinada ao público para o qual havia sido originalmente criado: a população de baixa renda. Em 1973, é instituído o Plano Nacional de Habitação Popular (PLANHAP) e, a partir de 1975, a chamada "Carteira de Operações Sociais", até então inexpressiva, passa a obter resultados quantitativos mais expressivos. Royer (2009) destaca que, em 1976, as COHABs passariam a atender também a faixa de renda de 3 a 5 salários mínimos, sendo parte significativa dos financiamentos destinada às faixas de 4 e 5 salários mínimos, o que seria responsável pela melhoria nos números referentes à atuação das Companhias.

Por fim, o quarto período equivaleria ao momento imediatamente anterior à crise que, a partir de 1983, acometeria o SFH e o BNH, e é quando são criados os chamados "programas alternativos": programas que visavam, basicamente, a auxiliar o já consolidado processo de autoconstrução da moradia pela população de baixa renda (dada a já constatada incapacidade do Sistema de solucionar as necessidades desta parcela da população) e/ou atuar na "reurbanização de áreas habitacionais degradadas", ou seja, não se destinavam prioritariamente à produção de novas unidades habitacionais (Santos, 1999:16). Esse é considerado "historicamente um período de redefinição da política de habitação popular" no país, no qual se gestam "programas reformistas" inseridos "na estratégia de transição democrática avançada pelo núcleo dirigente do regime" (Melo, 1989: 38). Sentindo o impacto de pressões sociais e econômicas, o regime - já em fim de linha - buscava renovar-se politicamente e legitimar-se socialmente através da adoção de políticas sociais pautadas em "intervenções que impactassem rapidamente sem, no entanto, reverter a condição estrutural na qual se encontravam as famílias moradoras de favelas e outros tipos de assentamento subnormais" (Royer, 2009: 58). 
11 A partir de então, os "lotes urbanizados" se institucionalizaram como "solução" política para o problema da habitação popular no país, disseminando-se em outras políticas públicas de ordem nacional e estadual, em uma perspectiva que retira da pauta do Estado a questão do direito universal à moradia (Pulhez, 2007:5,81).
São programas desse período: o PROFILURB Programa de Financiamento de Lotes Urbanizados (criado em 1975 e reformulado em 1978), o FICAM - Financiamento da Construção, Conclusão, Ampliação ou Melhoria de HIS (1977), o PROMORAR - Programa de Erradicação da Sub-habitação (1979) e o Projeto João de Barro - Programa Nacional de Autoconstrução (1984). Esses programas assinalam uma transição na atuação das COHABs, que, pela primeira vez, passam a produzir lotes urbanizados ${ }^{11}$ - indo na direção oposta de sua prática convencional de produção de grandes conjuntos - e a contemplar uma "clientela" com precária inserção no mercado de trabalho, marginalizada pela política oficial do Banco entre 1967 e 1974. Além disso, o João de Barro representou a primeira tentativa de um programa de autoconstrução em larga escala, diferenciando-se também por destinar-se prioritariamente a núcleos urbanos de pequeno e médio porte que, a essa altura, já eram os municípios que mais cresciam no país, como apontado adiante.

\section{Anos 1980 e 1990: a municipalização compulsória das políticas públicas}

No início da década de 1980, o regime militar apresentava evidentes sinais de desgaste e já estava em andamento um processo limitado e gradual rumo à transição democrática, através de um amplo conjunto de reformas, das quais os "programas alternativos" do BNH foram componente importante. Esgotado o modelo econômico até então vigente, uma forte crise abalaria o país, com o aumento acentuado da dívida externa, o recrudescimento da inflação, os altos níveis de desemprego, o rebaixamento dos salários, arrastando consigo a credibilidade dos militares e as bases sociais da ditadura, amplificando a oposição popular e acelerando o processo de abertura (cujo ápice seria a campanha Diretas Já!).

Transição pactuada, mudança sem rupturas: a chamada Nova República se configurará, desde o início, pela acomodação do projeto de reestruturação das políticas públicas setoriais (em especial as de caráter social) a um conjunto de ações pontuais, de caráter assistencial e emergencial (Melo, 1989). Nas esferas urbana e habitacional não seria diferente. Já no início do governo Sarney (1985-1990), os problemas do SFH, cuja crise financeira e institucional já se fazia sentir nos últimos anos do governo militar, agravaram-se sobremaneira, impactando decisivamente o funcionamento do BNH (Royer, 2009).

Nesse contexto, um amplo debate sobre o SFH foi levado a cabo no país, com a nomeação de um grupo de trabalho para debater sua reformulação, a formação de comissões para discutir encaminhamentos das políticas urbana e habitacional e o desenvolvimento de debates regionais sobre os rumos do $\mathrm{BNH}$. Entretanto, de maneira considerada abrupta por alguns analistas, o governo decretou a extinção do BNH em 1986, criando um "vácuo" no que tange às políticas habitacional e urbana, "através de um processo de desarticulação progressiva da instância federal, com fragmentação institucional, perda de capacidade decisória e redução significativa dos recursos disponibilizados para investimento na área" (Melo, 1989; Azevedo, 2007, Cardoso, s/d).

De fato, nos anos subsequentes, a dissolução das estruturas institucionais fez sentir seus efeitos, e uma profusão de órgãos se sucederam, sem resultados efetivos face à construção de políticas habitacionais e urbanas na Nova República:

Em um período de apenas quatro anos, o Ministério do Desenvolvimento Urbano (MDU), criado em 1985, transformou-se em Ministério da Habitação, Desenvolvimento Urbano e Meio Ambiente (MHU), em Ministério da Habitação e Bem-Estar Social (MBES) e, finalmente, foi extinto em 1989, quando a questão urbana voltou a ser atribuição do Ministério do Interior (ao qual o BNH era formalmente ligado). As atribuições na área habitacional do governo, antes praticamente concentradas no $B N H$, foram pulverizadas por vários órgãos federais, como o Banco Central (que passou a ser o órgão normativo e fiscalizador do SBPE), a Caixa Econômica Federal (gestora do FGTS e agente financeiro do SFH), o ministério urbano do momento (formalmente responsável pela política habitacional) e a então chamada Secretaria Especial de Ação Comunitária, a responsável pela gestão dos programas habitacionais alternativos (Santos, 1999:19).

Tal confusão institucional expressava a própria fragmentação das "políticas" subsequentes à extinção do BNH e a exacerbação da dissociação entre as esferas habitacional e urbana. Esgotado o padrão de financiamento até então vigente, 
ganhariam força, nesse período, os programas ditos "alternativos", agora geridos pela SEAC - Secretaria Especial de Ação Comunitária, caracterizando uma faceta própria aos governos Sarney e Collor no tratamento da questão habitacional: sua subordinação institucional como questão de assistência social. Nesse contexto, em 1989, a SEAC seria transformada em SEHAC (Secretaria Especial de Habitação e Ação Comunitária), vinculada ao Ministério do Interior, e passaria a abrigar, três anos após a extinção do $\mathrm{BNH}$, as atividades relacionadas ao que se dizia uma "política habitacional", com forte apelo "participativo". As poucas linhas de financiamento a fundo perdido para atendimento a famílias de até 3 salários mínimos que permaneceram ativas institucionalizavam definitivamente os sistemas de produção até então considerados "alternativos", como os programas de mutirão e os lotes urbanizados (Cardoso, s/d).

Estabeleceu-se, assim, uma clivagem entre as ações, cada vez mais destinadas ao público de renda média, intermediadas pelas $\mathrm{COHABs}$ - as quais, destituídas de seu papel de agentes promotores da política federal desde 1988, acabaram por configurar-se em "escritórios imobiliários de agentes privados que pretendiam atuar na faixa média do setor de habitação" (Melo, 1989) - e os programas alternativos da Nova República, geridos por municípios e outras entidades (em geral empresas públicas ou mistas) formadas com intuito de acessar recursos federais, os quais atendiam à população de menor renda.

O modelo institucional adotado privilegiava a iniciativa de estados e municípios, deixando de estabelecer prioridades alocativas: se, por um lado, a ausência de uma política efetiva acabaria por possibilitar maior autonomia aos governos estaduais e municipais, que deixam de ser apenas executores da política (Cardoso, s/d), por outro, tal autonomia, em um contexto de democratização ainda incipiente, resultaria em dinâmicas clientelistas, tanto no processo distributivista de alocação de recursos, quanto na seleção de localidades a serem contempladas, ou, ainda, em esfera local, no fato de que as ações se estabeleciam em resposta a conflitos pontuais (Melo, 1989).

A confluência entre esse processo de "autonomização" quase que compulsória dos municípios (que implicou um impulsionamento da descentralização das ações nas esferas habitacional e urbana e um paulatino processo de municipalização dos serviços públicos de modo geral, dada a ausência de políticas federais efetivas), a limitação da atuação das COHABs e o acelerado crescimento de cidades de pequeno e médio porte, em especial no estado de São Paulo (com todos os problemas daí decorrentes) parece ter sido a mola propulsora da constituição de uma nova leva de empresas públicas ou mistas, agora focadas na questão da hoje denominada habitação de interesse social. A título de exemplo, podemos citar: a PROGUAÇU - Empresa Municipal de Desenvolvimento e Habitação de Mogi-Guaçu (1986)، a PROHAB - Progresso e Habitação São Carlos (1986)، a Companhia Pública Municipal Pró-Habitação de Embu (1989), a EMHAP - Empresa Municipal de Habitação Popular de Santo André S.A (1990), a EMURJA - Empresa Municipal de Urbanização de Jaboticabal (1990), entre tantas outras.

Embora haja poucos estudos sobre a formação e atuação dessas instituições, não seria descabido aventar, a título de hipótese, que tais empresas diferentemente daquelas primeiras que, gestadas durante o regime militar e em pleno auge do $\mathrm{BNH}$, tinham como enfoque a captação de recursos federais para realização de grandes obras de desenvolvimento urbano nas principais cidades e regiões metropolitanas, uma vez que a questão habitacional estava a cargo das COHABs -, ao emergirem no contexto de extinção do $\mathrm{BNH}$ e de limitação da atuação daquelas Companhias, acabariam por atuar no "rastro" das mesmas, incorporando, de certa forma, seu modelo de atuação e direcionando suas ações à habitação social, tendo como mote principal a possibilidade de acesso aos parcos recursos disponíveis no período através dos já mencionados "programas alternativos".

Visando a examinar um pouco mais de perto os desdobramentos desse processo de municipalização compulsória do planejamento e das políticas urbanas e habitacionais, bem como a realidade desses órgãos, procederemos a um estudo de caso, investigando o processo histórico de constituição e consolidação da PROHAB, em São Carlos-SP. Para tanto, percorreremos inicialmente os caminhos trilhados pelo planejamento urbano no município, desde sua institucionalização até o seu ocaso, de modo a apreender os rumos institucionais que desembocarão na constituição da empresa analisada. 
12 Tabela adaptada de Devescovi (1987) e Dozena (2001). Devescovi utiliza como fonte dos dados os Censos Demográficos de 1940 a 1980; já Dozena se baseia no Anuário Estatístico do IBGE de 1996.

13Esta seção do trabalho tem por principal referência o trabalho de Lima (2007).

\section{São Carlos/SP: institucionalização e ocaso do planejamento urbano no município}

A partir de 1970, embora ainda concentrada nos grandes centros urbanos, a população brasileira passou por um significativo processo de reversão de sua polarização, em decorrência, principalmente, do desenvolvimento de um modelo espacial de crescimento econômico - em âmbito nacional e estadual - baseado na valorização das ditas "cidades médias". O chamado "milagre econômico brasileiro" irá repercutir, no estado de São Paulo, em um "transbordamento da indústria metropolitana": a estrutura industrial será estimulada, através de políticas federais de incentivo (com destaque para o Programa de Cidades Médias, implementado a partir de 1974), a se distribuir espacialmente, de forma gradativa e sempre seguindo os novos eixos rodoviários, dando margem a um processo de relativa descentralização/desconcentração espacial da indústria (Devescovi, 1987; Dozena, 2001).

Conforme reitera Lima (2007), a partir desse processo de "interiorização da indústria", as décadas de 1970 e 1980 efetivamente assistirão a um intenso desenvolvimento do interior de São Paulo: em 1970, 22 cidades do estado possuíam mais de 100 mil habitantes, em 1980, já eram 30 municípios com população entre 100 e 500 mil habitantes. Como um dos impactos desse processo sobre a dinâmica de urbanização do estado de São Paulo, Devescovi (1987) destaca a intensificação da diferenciação entre cidades e regiões na divisão territorial do trabalho: a região compreendida pelo eixo Ribeirão Preto Campinas (na qual se insere São Carlos) constituiu-se como uma das mais dinâmicas, em termos de inserção no processo de industrialização e de desenvolvimento do setor agrário, com grande capacidade de absorção de mão de obra e, consequentemente, grande atratividade de contingentes populacionais.

Nesse sentido, a partir da década de 1970, a repercussão desse processo se fará sentir em São Carlos, que assistirá a um grande crescimento industrial já nos primeiros anos da década: entre 1970 e 1975, a produção industrial local cresceu $253 \%$, enquanto que a média estadual alcançou $110,5 \%$. Entretanto, a industrialização em São Carlos não pode ser considerada significativa do ponto de vista de sua produção agregada, mas sim
- e muito - pela intensa urbanização engendrada nesse contexto, como se pode apreender na tabela abaixo, que demonstra que no período em questão (considerando-se desde a década de 1940 - quando a atividade industrial se torna já a principal fonte econômica do município - até a década de 1970 quando a interiorização industrial é levada a cabo no estado) os índices de urbanização de São Carlos superaram progressiva e significativamente as taxas nacionais e estaduais:

Evolução do índice de urbanização em São Carlos, no Estado de São Paulo e no Brasil (\%) ${ }^{12}$

\begin{tabular}{|c|c|c|c|}
\hline Ano & Brasil & $\begin{array}{c}\text { Estado de São } \\
\text { Paulo }\end{array}$ & São Carlos \\
\hline 1940 & 26,4 & 44,1 & 52,3 \\
\hline 1950 & 36,2 & 52,6 & 64,7 \\
\hline 1960 & 45,5 & 62,6 & 75,1 \\
\hline 1970 & 56,0 & 80,3 & 88,7 \\
\hline 1980 & 68,9 & 88,6 & 92,2 \\
\hline
\end{tabular}

Simultaneamente aos processos de deslocamento industrial para o interior do estado e de mudanças tanto na estrutura agrária como nas relações de trabalho na agricultura, o processo de urbanização das cidades inseridas nessas regiões mais dinâmicas - aí incluída São Carlos - se pautará pelo acirramento das chamadas "contradições urbanas", a partir do agravamento da pobreza nas cidades, ampliando significativamente seus espaços periféricos (Dozena, 2001; Fernandes, 2004; Devescovi, 1987).

Em São Carlos, embora o processo de periferização estivesse em curso desde pelo menos 1950, tendo se acentuado a partir de 1960, será entre os anos de 1970 e 1990 que se consolidarão as áreas periféricas da cidade, bem como se acirrará o processo de abertura de loteamentos irregulares e de ocupação precarizada de áreas ainda mais periféricas, resultando em uma expansão urbana absolutamente fragmentada, atingindo áreas ambientalmente frágeis e inadequadas para assentamento urbano e fazendo com que, em trinta anos - de 1970 a 2000 - dobrassem, em número, a população e a área de ocupação urbana (PMSC, 2003).

Será em meio a todo esse contexto que terá início um processo de institucionalização do planejamento urbano em São Carlos $^{13}$. Tal processo se inicia já na década de 1950, quando uma reestruturação 
administrativa municipal institui a criação de uma Diretoria de Obras e Viação (Lei Municipal 1751/53), entre cujas atribuições se incluíam a elaboração de planos urbanísticos e estudos sobre a expansão urbana (Lima, 2007:177). No mesmo ano, alguns meses antes, uma Lei Municipal (1716/53) já autorizava a Prefeitura a "contratar um arquiteto especialista para estudar o planejamento do Município de São Carlos". Na minuta que acompanha a Lei, uma espécie de termo de referência do serviço a ser contratado, observa-se uma sintonia - ao menos discursiva - entre a intenção de instituir um processo de planejamento urbano no município e os debates mais amplos sobre urbanismo e planejamento urbano que aconteciam no país desde a década de 1930.

Em 1959, será criada uma Comissão do Plano Diretor, a qual deveria elaborar e encaminhar o Plano à Câmara em um prazo de dois anos, além de, posteriormente à sua aprovação e a título contínuo, orientar e fiscalizar sua execução, emitir pareceres sobre ações municipais no campo urbanístico e, ainda, promover estudos e divulgação de conhecimento urbanístico no município (Lima, 2007:145). Em seguida, já na década de 1960, além da Comissão, será constituído também um Escritório Técnico do Plano Diretor, configurandose no primeiro órgão permanente de planejamento urbano no município, vinculado ao gabinete do prefeito. O processo de elaboração desse Plano (e a constituição do Escritório Técnico) contou com a assessoria técnica do Centro de Pesquisas e Estudos Urbanísticos (CEPEU), vinculado à Faculdade de Arquitetura e Urbanismo da Universidade de São Paulo (FAU-USP).

Em 1962, será concluído o primeiro Plano Diretor do município, cujo horizonte de planejamento era o crescimento da cidade até 140 mil habitantes (praticamente o dobro da população total do município naquele momento). Embora o Plano Diretor não tenha sido transformado em lei, algumas de suas diretrizes foram incorporadas na prática, e outras, em legislações, tal como a Lei de Loteamentos (lei municipal $n^{\circ} .4411 / 62$ ), que estabelecia normas para a aprovação e implantação de loteamentos no município.

Nas décadas de 1960 e 1970, conforme destaca Lima (2007), tal processo de institucionalização se confrontará com o descontrole da expansão urbana, decorrente da ação crescente de especuladores imobiliários. Seguindo os preceitos estabelecidos pela Lei Orgânica dos Municípios, promulgada pelo governo do estado de São Paulo em 1967, a qual vinculava a concessão de recursos estaduais aos municípios à aprovação de Planos Diretores, em 1968 será firmado um convênio com a Escola de Engenharia de São Carlos, visando à elaboração de tal Plano. Entre 1968 e 1970, será elaborado, nos moldes propostos pelo SERFHAU, o Plano Diretor de Desenvolvimento Integrado (PDDI), que contou com as assessorias técnicas do CEPAM - Centro de Estudos e Pesquisas de Administração Municipal e do IBAM - Instituto Brasileiro de Administração Municipal. Em 1971, o Plano será transformado em Lei (Lei Municipal 6684/71) e aprovado pela Câmara Municipal, bem como uma série de leis complementares de controle de uso e ocupação do solo por ele propostas.

Ao longo desse processo, uma nova reforma administrativa, também sob assessoria do IBAM, resultará na complexificação da estrutura administrativa municipal - que incorporará uma "assessoria de planejamento" permanente, vinculada ao gabinete do prefeito, bem como um novo departamento ligado às questões urbanas (além do já existente Departamento de Obras e Viação), o Departamento de Serviços Urbanos - e na descentralização administrativa territorial, através da criação das subprefeituras dos distritos de Água Vermelha e Santa Eudóxia.

Ainda que a operacionalidade desses planos possa ser questionada, é inegável a constatação de avanços, em termos de planejamento urbano, no município. Para elencar alguns: o próprio processo de institucionalização do mesmo, com a criação de órgãos específicos e a inserção das questões urbanas mais amplas no rol das propostas e ações da administração municipal; o aprofundamento do conhecimento acerca da realidade do município e o estabelecimento de diretrizes que, em menor ou maior escala, seriam incorporadas pelas ações municipais frente ao desenvolvimento urbano, além da estruturação de toda uma legislação urbanística municipal, que vigoraria até recentemente, quando da aprovação do Plano Diretor Participativo, em 2005.

Em termos de construção de um arcabouço legal de controle urbanístico, destaca-se, na década 
14Esta seção do trabalho foi desenvolvida tendo por base minha pesquisa de mestrado, cf. Rosa (2008). de 1960, a elaboração da Lei de Loteamentos, da Lei da Habitação e da Lei de Criação da Zona Industrial, tendo as mesmas se configurado como um marco inicial no controle da expansão urbana e no ordenamento do uso e ocupação do solo urbano. Já em 1971, o processo de elaboração do PDDI resultaria na promulgação de novas leis, articuladas entre si, modificando a estrutura da legislação urbanística municipal: Lei de Perímetro e Zoneamento, Lei de Edificações e Lei de Loteamentos. Em 1974, também um novo Código de Posturas foi aprovado no município, substituindo o anterior, datado de 1929.

Contudo, apesar desse processo de institucionalização do planejamento urbano no município e da construção desse arcabouço legal de controle urbanístico, as pressões especulativas do mercado imobiliário acabarão se sobrepondo a eles, direcionando, de forma perversa, os rumos da expansão e do desenvolvimento urbano do município. As próprias leis aprovadas em 1971 já continham permissividades bastante questionáveis acerca tanto do zoneamento quanto das condições de aprovação de loteamentos, e, em 1977, uma nova lei, correlata à Lei de Perímetro e Zoneamento, foi aprovada, e seus dispositivos permitiam que o perímetro urbano fosse alterado sem maiores limitações. Assim, conforme conclui Lima (2007:180), criaram-se as brechas para que os loteadores passassem a atuar de forma cada vez mais especulativa: "as consequências foram nítidas na cidade nos anos após 1977, com o sistemático crescimento da periferia, da segregação e da fragmentação do tecido urbano".

Nesse sentido, após todo esse processo, e a despeito da ausência de estudos específicos sobre o período pós-1977, é possível afirmar que o planejamento urbano entraria em ocaso no município, instaurando-se um vácuo institucional e legal que, de alguma forma, estaria em diálogo com a situação do planejamento urbano em esfera nacional, tendo em vista o encerramento de um ciclo de institucionalização do planejamento no país com a extinção do SERFHAU, em 1975. De fato, somente em 1985 será constituído um novo órgão destinado a enfrentar a questão urbana no município, a PROHAB - Progresso e Habitação São Carlos. Porém, como demonstrado adiante, seu enfoque será bastante pontual e concentrado na resolução de questões urbanas emergenciais, ligadas diretamente à problemática da habitação de interesse social no município.

De modo mais amplo, a estrutura administrativa do município somente sofrerá nova alteração em 1997 (através da Lei Municipal 11261/97), quando se consolidará sua organização em Secretarias, e serão constituídas a Secretaria Municipal de Obras e Serviços Públicos e, finalmente, a Secretaria Municipal de Habitação e Desenvolvimento Urbano, à qual competiria "executar e controlar o uso e ocupação [sic] do solo urbano; coordenar e executar a política de habitação no âmbito do município; em especial a política de habitação popular; lotes urbanizados [sic]; promover e acompanhar o desenvolvimento urbano, cumprindo e fazendo cumprir o estatuido [sic] no Plano Diretor" (cf. Lei Municipal 11261/97, artigo 26). Apesar das referências, nessa Lei, ao Plano Diretor como um dos "documentos básicos da Administração Municipal", e de um amplo debate sobre o tema articulado pelo Departamento de Arquitetura e Urbanismo da Escola de Engenharia de São Carlos no mesmo período, um novo processo de elaboração de um terceiro Plano Diretor só se iniciou em 2003, tendo sido o mesmo aprovado em 2005, sob coordenação da Secretaria Municipal de Habitação e Desenvolvimento Urbano e com assessoria técnica de docentes do mesmo Departamento de Arquitetura e do Instituto Polis.

\section{PROHAB - São Carlos/SP: constituição e consolidação de uma empresa mista ${ }^{14}$}

\section{Primórdios: a polêmica da CODESCAR}

Na década de 1970, a questão da moradia para a população de baixa renda estava na ordem do dia dos debates políticos em São Carlos: a intensificação do processo de urbanização e periferização da cidade repercutia em acaloradas discussões, na Câmara Municipal de Vereadores, acerca dos "altos aluguéis cobrados na cidade", das "dificuldades das familias de trabalhadores" e da "necessidade de casas populares". Em paralelo - e não por acaso - o crescimento vertiginoso de loteamentos irregulares e clandestinos é assunto que se tornará recorrente no mesmo período, estendendo-se por anos a fio.

Naquele momento, teve início uma ocupação que viria a se configurar como "a primeira favela de São 
15Cf. Falkoski (1988).

16 Cf. Ata da Câmara Municipal de São Carlos, 09 de abril de 1979 e Jornal

A Folha: "A triste sina dos favelados no Pacaembu", 11 de fevereiro de 1979; "Caso das Favelas. Vereador quer crucificar o vice-prefeito", 14 de fevereiro de 1979.

17 Cf. Atas da Câmara Municipal de São Carlos: 26 de março; 09 de abril; 30 de abril e 07 de maio de 1979.

18Tais como o Terminal Rodoviário, a Casa de Cultura, a Praça Coronel Salles, o Kartódromo e o Clube de Motocross (cf. diversas atas da Câmara Municipal de São Carlos consultadas).

19 Para uma abordagem detalhada do período, ver Rosa (2008).

20 Cf. Ata da Câmara Municipal de São Carlos, 03 109/1984; Processo da Câmara Municipal de São Carlos n 968/84.

21 Idem. Tal declaração aponta para o mote que teria estimulado a criação de inúmeras empresas públicas e mistas desde a década de 1970 no país: a possibilidade de captação de recursos mais significativos junto aos governos federal e estadual. Vejase, nesse sentido, Heck (2004).

22 Cf. Jornal O Diário, "Os vereadores, como marionetes?", 2 de setembro de 1984 (constante do Processo da Câmara Municipal de São Carlos n 968/84).

${ }^{23}$ Cf. Processo da Câmara Municipal de São Carlos no 968/84.
Carlos", conhecida como "Favela do Gonzaga". Entretanto, sua descoberta "oficial" se daria apenas em 1979, quando cerca de quarenta famílias já viviam no local ${ }^{15}$, e não havia mais como "a cidade" ignorar a ocupação que ali se adensava: aquele ano seria o primeiro a ver emergir nas atas da Câmara Municipal e nos jornais ${ }^{16}$ a Favela, considerada por décadas como o principal "problema social e urbano" de São Carlos.

Imediatamente após o anúncio da existência da Favela, teria início uma série de visitas de comitivas oficiais à área, desembocando na constituição de uma comissão responsável por desenvolver levantamentos e propostas para "solucionar o problema"17. Esse processo reacenderia a discussão sobre as demandas por habitação popular na cidade, bem como sobre a ausência de infraestrutura na periferia, e traria à tona o questionamento quanto a grandes obras que estariam sendo priorizadas pela gestão municipal ${ }^{18}$ em detrimento do atendimento às "necessidades do povo", como a "construção de casas populares".

Entretanto, nos anos subsequentes à sua descoberta, o "problema da favela" praticamente desaparece dos debates públicos municipais, em razão de motivos diversos que não caberia a este artigo detalhar. ${ }^{19}$ Durante esse período, a favela cresceria vertiginosamente e assumiria proporções que tornariam inevitável seu reaparecimento, ainda mais incisivo, como uma "grande ferida" na cidade, em meados dos anos 1980, uma vez que a postura desenvolvimentista da gestão municipal em curso desde 1983 - que tinha como uma de suas grandes preocupações políticas a transformação do município em uma "região administrativa" - não combinava com a presença, cada vez mais consolidada, de uma favela na cidade:

São Carlos tem uma ferida, que é a Favela do Gonzaga, com cerca de 260 casas, construídas precariamente, constituindo-se num problema social que vem perturbando a sociedade são-carlense. (...) É um problema angustiante, que não se coaduna com a cultura e o progresso desta cidade. (Ata da Câmara Municipal de São Carlos, 10/06/1985)

Assim, o "problema-favela" iria ressurgir no debate político e passaria a pautar, desde então, boa parte dos rumos da incipiente política urbana local, a partir da polêmica em torno da proposta, apresentada pela
Prefeitura Municipal, de criação da CODESCAR Companhia de Desenvolvimento de São $\operatorname{Carlos}^{20}$.

A CODESCAR seria uma sociedade de economia mista destinada à "realização de atividades de caráter social, comercial e industrial", que se propunha a uma atuação de enorme abrangência, abarcando "os problemas que mais afetam a população, como: habitação - infra-estrutura - eletricidade educação - abastecimento - comercialização de gêneros alimentícios - desemprego - execução de obras e serviços públicos" e revestindo-se de um caráter ambíguo em termos de sua autonomia em relação aos poderes executivo e legislativo municipais. A principal justificativa da proposta, inicialmente, seria a resolução dos "problemas mais urgentes do cotidiano do município", alegando que, por permitir a "dispensa de certas formalidades legais" - como, por exemplo, a realização de licitações - poderia agilizar tais soluções, uma vez que "a administração pública por si só carece[ria] de meios para resolver prontamente todos esses casos que angustiam a população, tendo em vista, principalmente, a carência de recursos que vivem os municípios"21.

A polêmica estabelecida entre os vereadores e insuflada pela mídia local ${ }^{22}$ trazia muitos questionamentos sobre o projeto e acusava-o de "mal-intencionado", uma tentativa de instalação de um "poder paralelo" no município, que pretenderia desvincular do Legislativo grande parte das decisões sobre o desenvolvimento municipal. Ao passar pela Comissão de Obras e Serviços Públicos da Câmara, um dos pareceres favoráveis apontava, dentre os argumentos que justificariam a criação de tal empresa, aquele que seria adotado como principal "bandeira de defesa" do projeto - a intenção de promover o "desfavelamento": "É uma iniciativa que visa a agilizar a administração. Entre as vantagens sociais que a CODESCAR poderá trazer está o desfavelamento que, por si só, já justifica a aprovação." 23

A partir de então, em escancarada manobra política, a resolução do "problema-favela" passaria a ser acionada como benefício maior a ser alcançado com a criação de tal Companhia, ainda que no próprio projeto de lei fossem feitas apenas menções pontuais à questão da "erradicação das favelas", em meio a inúmeras outras demandas que seriam objeto da atuação da empresa. Contudo, 
24 Cf. Ata da Câmara Municipal, 17 de setembro de 1984; Processo da Câmara Municipal $n^{\circ}$ 968/84.

25 Cf. Processo da Câmara Municipal n 1244/84. O processo em questão questiona a Prefeitura Municipal a respeito da possibilidade de implementação do Projeto João-de-Barro - Programa Nacional de Autoconstrução, do BNH, como alternativa para solucionar o problema da Favela do Gonzaga.

26 Veja-se, aqui, um claro indício no sentido da hipótese levantada ao fim da segunda seção deste texto, sobre o mote de constituição de tantas empresas públicas ou mistas a partir da segunda metade dos anos 1980.

27 Cf. Ata da Câmara Municipal de São Carlos, 19 de agosto de 1985. quando da votação do projeto, o desfavelamento se transformaria efetivamente em tema central da discussão, como forma de pressionar o Legislativo a aprová-lo.

De fato, em função de toda essa polêmica, o projeto, apresentado à Câmara em julho de 1984, só seria votado em setembro do mesmo ano, na última sessão ordinária antes que expirasse o prazo para apreciação do mesmo. No dia da votação, a oposição manobrou uma estratégia para tentar impedi-la, fazendo um uso perverso das necessidades dos moradores da Favela: dois ônibus fretados e carros oficiais trouxeram os moradores para promover manifestações em prol da CODESCAR ao longo da sessão, sob o pretexto de que o grande objetivo da Companhia seria resolver o "problema-favela".

No entanto, apesar da pressão dos manifestantes (que carregavam placas com os dizeres "CODESCAR já", defendendo uma causa que não necessariamente era a sua), após polêmica e disputada votação, o projeto foi rejeitado por nove votos a oito, com o voto de minerva do presidente da Câmara. Dentre os favoráveis à aprovação, os principais argumentos acionados apoiavam-se em propostas tão distintas como o "desfavelamento" e o "apoio ao esporte" - tamanha a envergadura pretendida por tal Companhia, que abarcaria quase todas as esferas das políticas públicas municipais. Recorrendo a iniciativas implantadas em outras cidades - como Limeira, onde companhia semelhante teria "desfavelado 200 famílias" - afirmavam:

CODESCAR é sinônimo de desfavelamento, sendo esse um compromisso que o Prefeito Dagnone de Melo e sua equipe assumiam com os favelados de São Carlos, sendo também progresso, fazer justiça social, incrementar os esportes, gerar empregos. (...) CODESCAR igualmente é a produção de alimentos mais baratos, é vender lotes mais baratos, é cultura, água e esgoto. (Ata da Câmara Municipal de São Carlos, 03/09/1984)

E por que tamanha benesse ao município seria negada pela Câmara? Os opositores do projeto alegavam que tal Companhia pretendia ser uma forma de o governo municipal escapar ao controle do Legislativo e, rebatendo a estratégia do governo, procuravam desvincular a resolução do "problema-favela" do projeto de lei em questão, no qual, afirmavam, fazia-se "apenas uma ligeira citação ao desfavelamento". Reafirmando que "os favelados já deviam ter sido atendidos pela atual administração", diversos vereadores assumiram publicamente o "compromisso de votar a favor de um novo anteprojeto que proponha especificamente o desfavelamento" e de "aprovar toda e qualquer matéria que desfavele e beneficie o povo, sem que escondam objetivos obscuros". 24

Compromissos assumidos de ambos os lados, no dia seguinte à votação, dois processos direcionados mais especificamente ao desfavelamento seriam abertos na Câmara Municipal, apontando a necessidade de se "promover o desfavelamento em São Carlos" e questionando o poder executivo quanto às providências nesse sentido ${ }^{25}$. A resposta oficial procurava trazer à baila, novamente, o importante papel que poderia ser desempenhado por uma empresa como a CODESCAR:

O Sr. Prefeito pretende construir casas aos favelados em áreas vizinhas à favela do Gonzaga. A CODESCAR poderia fabricar a maioria dos materiais para as casas, contratar mão de obra dos favelados e ser o Agente Financeiro junto ao BNH26. Os favelados com a colaboração do povo São-Carlense construiriam as casas, pelo sistema multirão [sic], e teriam casas mais baratas. (Processo da Câmara Municipal de São Carlos no 1244/84)

\section{A Favela dita os rumos da incipiente política urbana municipal: a criação da PROHAB}

Em agosto de 1985, quase um ano após toda essa polêmica, a Prefeitura propõe um novo projeto de constituição de uma empresa mista, agora denominada PROHAB - Progresso e Habitação São Carlos. Votado em "regime de tramitação urgente", em uma única discussão, esse processo reacende as disputas em torno do mote "favela": "não há necessidade de se criar uma empresa para erradicar uma favela", contestam alguns vereadores. Por outro lado, fala-se sobre a "reconhecida necessidade de erradicação dessa favela" como forma de defender o projeto. Mais do que nunca, a Favela era o alvo que se pretendia atingir com a criação de uma empresa mista voltada ao "progresso" e à "habitação" em São $\operatorname{Carlos}^{27}$. 
28Cf. Processo da Câmara Municipal de São Carlos $n^{\circ} 674 / 85$.

29 Idem.

300 segundo objetivo contemplaria a proposição de "venda de gêneros alimentícios de primeira necessidade", de cuja implementação não se tem notícia.

31 Efeito do já mencionado processo de municipalização das políticas habitacionais, a disseminação, no estado, de empresas municipais de habitação, bem como a criação do "Programa Municipal de Habitação", da Companhia de Desenvolvimento Habitacional do Estado de São Paulo se darão nesse contexto.
A proposta, quando apresentada, já apareceu bastante modificada em relação ao antigo projeto de criação da CODESCAR, tendo o foco mais direcionado à "solução de problemas de habitação e urbanização" do município, ou seja, apresentando-se como um órgão destinado a concentrar as políticas habitacional e urbana municipais, institucionalmente órfãs, como visto, desde meados dos anos 1970. Entretanto, o escopo apresentado ainda era bastante vago, abrangendo também "atividades de caráter social, comercial e industrial", e não enfocava especificamente-como pretendiam os vereadores da oposição - a "erradicação de favelas", que aparecia em meio a diversas outras atividades previstas. Após dois meses de negociação com os vereadores, a Prefeitura apresentou à Câmara Municipal uma nova proposta, com algumas alterações, dentre as quais o direcionamento de seu escopo para a exclusiva "realização de atividades de caráter social". ${ }^{28}$

Mas os vereadores ainda desconfiavam da matéria e propuseram diversas alterações no sentido de explicitar que os objetivos prioritários da referida sociedade de economia mista fossem "resolver os problemas das favelas que já muito tempo reclama [sic] solução por parte dos Poderes Municipais" e "vender diretamente gêneros alimentícios de primeira necessidade para o povo" 29 . Desse modo, o redirecionamento de tal empresa para a erradicação da Favela justificaria sua aprovação, resultando na estratégica redação final do objetivo primeiro da empresa ${ }^{30}$ :

Execução da política habitacional do município, estudando e propondo planos para Habitação, na erradicação de favelas prioritariamente, aproveitando áreas ociosas ou mal destinadas, que com o devido estudo urbanístico atendam ao proposto neste item. (Lei Municipal no 9.348/85)

O município contava agora com um órgão especialmente direcionado à "execução de sua política habitacional", algo realmente inédito em sua história urbana, e não seria equivocado afirmar que a constituição da PROHAB - e mais: os moldes adotados pela empresa - somente foi possível em função do "problema urbano" materializado na Favela do Gonzaga, atestando o papel significativo que esta assumiu no direcionamento das políticas públicas urbanas e habitacionais do município. De fato, como apresentado a seguir, em sua primeira década de atuação, a PROHAB voltará intensamente seu foco para as tentativas de resolução de tal "problema", desde a perspectiva inicial de erradicação da Favela, através da realização de um mutirão, até a execução de uma "urbanização em tempo recorde", concluída nos primórdios dos anos 1990, que traria visibilidade e consolidaria a atuação da PROHAB no município, uma vez que esta teria, supostamente, cumprido com aquele que seria o objetivo primeiro de sua criação.

A despeito da falta de informações sobre a estrutura interna inicial assumida pela PROHAB, bem como sobre os projetos levados a cabo pelo órgão anteriormente aos anos 2000 (devido à quase total inexistência arquivos do período), intenta-se, a seguir, reconstruir os "primeiros passos" da empresa, de modo a apreender, ainda que parcialmente, alguns aspectos operacionais, suas conjunturas específicas e conexões mais amplas com o panorama das políticas urbana e habitacional em âmbito nacional.

\section{A atuação da PROHAB em São Carlos: breve panorama e algumas considerações}

Tendo as discussões sobre a constituição de uma empresa mista em São Carlos se encaminhado conforme o descrito, completamente sustentadas pela perspectiva da erradicação da Favela do Gonzaga, não causou estranhamento encontrar, em meio ao processo da Câmara Municipal relativo ao projeto de lei que criaria a empresa, uma cópia do "Programa Desfavelamento", da EMURP - Empresa Municipal de Urbanização de Pederneiras (datado de junho de 1985). Utilizado como argumento para justificar a importância de uma empresa municipal na concretização do tão desejado desfavelamento, tal Programa, que propunha a construção de 100 unidades de $28 \mathrm{~m}^{2}$ em regime de mutirão, foi uma das referências para a proposta que seria elaborada pela recém-criada PROHAB, visando à "erradicação da favela do Gonzaga".

Além disso, a presença desse Programa em meio ao processo dá indícios, ainda, de que o "desfavelamento" através da construção de habitações mínimas em regime de mutirão era uma política que, propugnada pelo $\mathrm{BNH}$, já proliferava no interior do estado de São Paulo ${ }^{31}$, conforme haviam deixado entrever, também, outras referências 
32 Cf. Processo da Câmara Municipal n 968/84.

33 Leis Municipais $n^{\circ}$ $9448 / 86$ e $9449 / 86$.

34 Entre as duas intervenções na "Favela do Gonzaga" - iniciadas, respectivamente, em 1986 e 1989 - a PROHAB teria executado apenas mais uma ação: a construção do empreendimento São Carlos III, um conjunto de 366 unidades no bairro Santa Felícia (cf. PROHAB/ TEIA, 2010).

$35 \mathrm{~A}$ institucionalização das urbanizações de favelas em âmbito municipal decorrerá de uma "estranha confluência" entre as pressões dos novos movimentos sociais e o "ideário reformista da Nova República" (Pulhez, 2007:83;239).

\section{$36 \mathrm{Cf}$. PROHAB (s/d).}

37 A perspectiva de firmar tal convênio moverá todo o processo de urbanização, tendo os órgãos municipais envolvidos acreditado que este se concretizaria e mantido todos os procedimentos exigidos pelo convênio até o momento da inauguração das obras. mobilizadas por vereadores quando das discussões sobre o papel da CODESCAR e, posteriormente, da PROHAB, como os exemplos de Limeira, Americana, Franca, Ribeirão Preto e Osasco. ${ }^{32}$

Seguindo tais exemplos, portanto, a PROHAB inicia sua atuação na cidade tratando de encaminhar a tão esperada "erradicação da Favela do Gonzaga" através de convênio firmado em janeiro de 1986 com a Companhia de Desenvolvimento Habitacional do Estado de São Paulo - CDH. De acordo com as regras do "Programa Municipal de Habitação", da $\mathrm{CDH}$, a Prefeitura cederia o terreno, o governo do Estado disponibilizaria o material de construção e a contratação de uma equipe de assessoria técnica para o acompanhamento da obra, e os moradores entrariam com a mão-de-obra, através de mutirão: a "organização de participação da população beneficiária" era uma das regras do referido Programa, contemplada pelas leis aprovadas ${ }^{33}$ na Câmara Municipal.

Em meados de 1986, teria início a primeira etapa do "mutirão para a erradicação da Favela do Gonzaga", com o cadastramento das 280 famílias que ali moravam, a seleção de 80 delas para participar do mutirão, a realização de reuniões para 'escolha' do projeto da casa e o início das obras. A partir de então, durante dois anos, a Favela seria alvo de intervenção: em linhas gerais, a proposta original era desadensá-la através da remoção dessas primeiras famílias para a área onde seria realizado o mutirão e, em uma segunda etapa, realizar outro mutirão, "erradicando-a" definitivamente. Entretanto, apenas a primeira etapa logrou concretizar-se, e a Favela permaneceu adensando-se.

A gestão municipal seguinte manteria a favela como alvo prioritário de intervenção da $\mathrm{PROHAB}{ }^{34}$, sob novo enfoque: dez anos após sua "descoberta", em 1989, uma conjuntura bastante específica iria desencadear, em âmbito municipal, uma mudança no discurso oficial sobre as formas de lidar com o "problemafavela" - da postura de "erradicação" para a ideia de "urbanização". Diversos fatores contribuiriam para essa mudança, a começar pela existência de uma demanda organizada dos moradores, associada a pressões de vereadores e da Igreja Católica e, em um contexto mais amplo, aquele redirecionamento sociopolítico no tratamento da questão habitacional e urbana no país ${ }^{35}$, que teria ecos na criação da
SEHAC - Secretaria Especial de Habitação e Ação Comunitária (órgão que, bem ou mal, seria decisivo para a urbanização da Favela do Gonzaga).

Assim, com uma agilidade pioneira no trato da questão, poucos meses após o início da nova gestão municipal seriam retomados os trâmites para a urbanização da Favela, o que se faria "em tempo recorde ${ }^{136}$. O caráter de urgência com que o processo de urbanização foi encaminhado por essa gestão parece ter sido determinado - mais até do que pela pressão de agentes como os moradores, os vereadores e a Igreja Católica, ou, ainda, pela dinâmica intensa de crescimento e precarização da Favela - pela promissora perspectiva que se apresentava ao governo municipal de estabelecer um convênio com o governo federal, através do Programa Mutirão Habitacional Comunitário Subprograma Lotes Beneficiados, da já mencionada SEHAC, e que exigiria agilidade para efetivá-lo.

A proposta de urbanização adotada seria determinada significativamente pelas regras que regeriam tal convênio, que, afinal, nunca se concretizou ${ }^{37}$. A começar pelo prazo estipulado para a urbanização: os seis meses anunciados inicialmente pela Prefeitura e os nove meses nos quais a intervenção foi efetivamente realizada correspondem exatamente aos cento e oitenta dias, prorrogáveis por mais sessenta, determinados pelas regras do convênio que se esperava firmar com a SEHAC. Inclusive a própria opção pela "urbanização" da Favela parece ter sido decorrente de tal perspectiva de convênio, o qual previa o financiamento de "lotes urbanizados" associados à construção de "embriões habitacionais" ("unidades sanitárias básicas"), determinando, de antemão, também os moldes e limites da intervenção.

Tais moldes e limites seriam delineados, portanto, por um conjunto bastante claro de premissas que passavam a orientar as "políticas públicas" nacionais voltadas à questão das favelas e "assentamentos precários" naquele momento - prazos exíguos; poucos recursos; foco em "melhoramentos urbanos", sem perspectiva de resolução da questão habitacional (cuja responsabilidade seria repassada ao próprio morador); vinculação ao "auxílio da comunidade" - contribuição com mão-de-obra para a intervenção, além da demanda por um tipo de "participação" específica dos moradores, que 
38 A urbanização efetivada consistiu basicamente em obras de infraestrutura, demarcação dos lotes, em parte tomando como referência a própria localização dos barracos, e construção de duzentos e sessenta e nove banheiros - as denominadas "unidades sanitárias básicas". Cf. PROHAB (s/d). deveriam estar "organizados" em torno de uma "Sociedade Comunitária Habitacional".

Pautando-se, portanto, essencialmente pela normativa da SEHAC, um ano e quatro meses após iniciada a nova gestão, a Prefeitura, através da PROHAB, declararia urbanizada a Favela ${ }^{38}$. A forma como a urbanização aparece nas atas da Câmara Municipal e em documentos de divulgação da época - uma rápida sequência de ações que culmina na simbólica renomeação oficial da Favela do Gonzaga como "Jardim Gonzaga" - é significativa para sua compreensão: em junho de 1989, seria feita uma reunião na qual se deliberou que "a administração municipal aceitava o desafio e urbanizaria a Favela"; já no mês seguinte, seria fundada a Sociedade Comunitária de Habitação Popular de São Carlos e encaminhado o convênio com a SEHAC; em agosto, a licitação para a execução das obras já havia sido realizada e seriam feitos os serviços de locação e demarcação dos lotes e futuras vias públicas; dois meses depois, teria início a implantação das redes de água e esgoto, a abertura das ruas e a terraplanagem; em novembro, seria promulgada a Lei Municipal $n^{\circ}$ 10.210/89, concedendo "à Sociedade Comunitária de Habitação Popular de São Carlos subvenção, destinada à urbanização da FAVELA DO GONZAGA"; nos meses seguintes, seriam concluídos todos os demais serviços, sendo, as obras, inauguradas de forma pomposa em 21 de abril de 1990, contando com a presença de representantes políticos municipais e estaduais, representantes da Igreja Católica, além dos moradores; poucos dias após a inauguração, a Lei Municipal n 10.292/90 renomearia oficialmente a Favela do Gonzaga: estava criado, legalmente, o bairro "Jardim Gonzaga". Tal intervenção, a despeito de todos os problemas dela decorrentes, os quais não caberia aqui avaliar, consolidou-se na memória urbana de São Carlos como um dos maiores feitos da PROHAB na cidade.

Após essa primeira sequência de intervenções da empresa frente ao "problema da favela", a documentação encontrada sobre o período entre 1990 e 2000, ainda que escassa, evidencia dois momentos distintos de atuação do órgão no município. Entre os anos de 1990 e 1996 não há registro de projetos levados a cabo pela empresa; revela-se apenas, na documentação pesquisada, que, nos anos de 1994 e 1995, houve, por um lado, repasses de recursos destinados a "cobertura dos déficits de manutenção" da empresa (Lei Municipal 10.946/94), evidenciando possíveis problemas financeiros e administrativos, e, por outro, tentativas de ampliação de seu escopo, numa manobra aparentemente destinada a redirecionar a atuação da empresa para atividades mais "lucrativas". Com efeito, em 1995, a despeito de todas aquelas polêmicas iniciais em torno dos objetivos da constituição de uma empresa mista na cidade, o então prefeito municipal propôs uma lei alterando as finalidades da PROHAB, de modo a incluir algumas das atividades previstas naquela proposta de criação da CODESCAR, ampliando significativamente o escopo de possibilidades de atuação da empresa, que, além da realização de atividades de "caráter social", passou a poder desempenhar também atividades de "exploração e execução de serviços públicos e de expansão industrial".

Entre 1996 e 1998, são executados dois grandes "loteamentos sociais": o Santa Angelina (914 lotes urbanizados) e São Carlos VIII (1089 lotes urbanizados). Únicas iniciativas da PROHAB no sentido de promover, produzir e comercializar lotes urbanizados, elas parecem reproduzir o modelo de atuação levado a cabo pelas $\mathrm{COHABs}$ no último período de atuação do $\mathrm{BNH}$, inclusive em termos da magnitude dos loteamentos, bem como de sua localização nas periferias extremas e totalmente desconectadas da cidade.

Dos anos 2000 em diante, a atuação do órgão esteve focada quase que exclusivamente na produção de novas unidades habitacionais, através de projetos elaborados ao sabor dos financiamentos disponibilizados pelo governo federal, não chegando a 1000 o número de unidades produzidas até 2010. Outras iniciativas ganharam força, tais como uma usina de produção de artefatos de cimento e a execução de algumas obras públicas com esses materiais produzidos, como praças e pavimentação de vias. Por fim, vale destacar que, passados quase vinte anos da criação da PROHAB sob o mote do desfavelamento, e quinze anos da referida "urbanização em tempo recorde", em 2004 o Jardim Gonzaga voltou a ser alvo de atuação da empresa (em parceria com Secretarias Municipais), em um Projeto de Urbanização Integrado que, financiado pelo Programa Habitar Brasil Bid, se configuraria publicamente como a maior intervenção urbana 
"de interesse social" da história do município (PROHAB/TEIA, 2010; Baron, Anelli, 2009; TEIA, 2002).

\section{Planejamento urbano e política habitacional: qual o papel do município?}

Perscrutando os caminhos da construção e consolidação da PROHAB no município de São Carlos, faz-se visível o quão complexos são os imbricamentos entre as diretrizes mais amplas das políticas federais ligadas ao planejamento urbano e à habitação (ou a ausência delas) e as conjunturas específicas das realidades locais dos municípios. Entre a mera reprodução de um modelo ou de um discurso e a configuração de um modus operandi próprio de cada cidade (ou de cidades cujas configurações e problemáticas urbanas se assemelhem), parece haver uma tênue e móvel fronteira, que a cada momento tende a aproximar-se de um dos polos, fazendo-os simultaneamente complementares e conflitantes.

No caso da PROHAB, parece evidente que a iniciativa de constituição de uma empresa mista voltada a questões urbanas e habitacionais de um município específico parte de objetivos aparentemente genéricos, tendo em vista, entretanto, uma meta suficientemente clara - e, ao que tudo indica, compartilhada pelas inúmeras empresas públicas e mistas constituídas entre as décadas de 1970 e 1990 : a obtenção e a utilização facilitada de recursos federais (e estaduais) destinados a melhoramentos urbanos e habitacionais. Entretanto, como o mesmo caso indica, demandas e disputas localizadas conferem especificidade seja ao processo de constituição, seja ao formato adotado ou à atuação propriamente dita de tal empresa, segundo rumos nem sempre previstos inicialmente.

Por um lado, são evidentes as iniciativas modelares, incorporando discursos e reproduzindo modelos de intervenção difundidos em escala nacional, como é o caso tanto das ações destinadas à "erradicação" da Favela através de processos de "mutirão", quanto da mudança de postura para o âmbito diametralmente oposto, inserindo-se nos parâmetros da "urbanização de baixos padrões", ou, ainda, na perspectiva de produção de imensos loteamentos populares periféricos, absolutamente desconectados da cidade.
Por outro, tais opções são também resultados de arranjos e ajustes locais, sejam eles a pressões sociais, a opções de financiamento disponíveis aos municípios em dado momento, a interesses políticos em jogo na escala local, ou a necessidades econômicas da própria empresa, para citar alguns exemplos observados no caso estudado.

De todo modo, resta claro, ao menos em relação à $\mathrm{PROHAB}$, que a constituição de um órgão específico destinado a "executar a política habitacional do município" padece de um equívoco de origem: a quem caberia planejar tal política? Conforme analisou Melo (1989:43), já nos primórdios do processo de municipalização das políticas urbana e habitacional e desresponsabilização do Estado no nível federal:

Um padrão de intervenção que parece estar se desenhando na esfera local é o que se poderia denominar padrão reativo. Com efeito, a ação dos órgãos locais tem se pautado pela ausência absoluta de critérios e procedimentos típicos de planejamento (fixação de metas, preocupações com o médio e longo prazo, etc). Pelo contrário, as ações constituem respostas a conflitos pontuais que eclodem na arena local.

É inevitável constatar que, em esfera local, acentuase ainda mais a completa desarticulação entre habitação e planejamento urbano (ou, mesmo, a uma política urbana de modo geral). E - por que não dizer? - evidencia-se a paulatina substituição do temário abrangente do planejamento urbano pela perspectiva setorial da habitação (e, ainda mais, da habitação de interesse social), processada desde os primórdios da constituição do BNH (e de sua sobreposição ao SERFHAU), seguida da consequente desresponsabilização neoliberal do Estado, em todos os níveis, frente às questões urbanas e habitacionais como um todo, caminhando em sentido absolutamente contrário ao processo de legitimação do urbanismo, de institucionalização do planejamento urbano, de discussão acerca da necessária integração entre habitação e urbanismo construído ao longo de quatro décadas (1930 1970) por diversos profissionais e instituições da área no país.

Nesse sentido, a despeito da já nem tão recente aprovação do Estatuto da Cidade, da criação 
do Ministério das Cidades e da consolidação de uma Política e um Plano Nacional de Habitação (estes últimos suplantados, de última hora, pelo Programa Minha Casa, Minha Vida), a questão urbana ainda resta desconectada, fragmentada em "programas urbanos", e o planejamento urbano, reduzido a uma pasta em nível departamental. A elaboração e a revisão de Planos Diretores e de inúmeros planos setoriais, cada vez mais sob responsabilidade quase que exclusiva dos municípios, permanecem descoladas, em sua grande maioria, de uma perspectiva governamental integrada, sendo delegadas a organizações e empresas de consultoria, em sua grande maioria "transmunicipais", ou seja, sem vinculação específica a qualquer município, atuando apenas como "prestadoras de serviços". Em certa medida, não seria equivocado afirmar que tal modus operandiseria decorrente do esvaziamento da noção de planejamento urbano ocorrido desde os anos 1960 no país, tratando-se, talvez, do ápice daquele processo que alguns autores denominaram de "divórcio entre técnica e política" e que resultou numa perspectiva cada vez mais tecnicizada da política e do planejamento urbanos.

De acordo com Feldman (2005:12), esse processo poderia ser encarado como consequência da inserção decisiva, no que a autora chama de "arranjo SERFHAU", da possibilidade de contratação, pelos governos municipais, de empresas de consultoria para a elaboração dos planos: disso resultaria "que, no Brasil, a partir dos anos 1960, é sobretudo fora das instituições de urbanismo das administrações públicas que se constrói a prática de elaboração de planos, em equipes multidisciplinares, e onde se dá de forma massiva a formação de quadros técnicos qualificados".

Nesse ponto, mais do que conclusões, restam aqui indagações: qual seria o lugar do planejamento urbano hoje no país? Ainda seria possível pensar na efetiva articulação entre planejamento e políticas urbana e habitacional? Qual o lugar do município, qual o papel de seus órgãos governamentais voltados às questões habitacional e urbana? Recuperando a principal crítica ao planejamento desde os tempos do SERFHAU, em que medida a "terceirização" do planejamento tem resultado em maiores operacionalizações ou "eficácias" dos planos? Que cidades têm sido produzidas nesse contexto?

\section{Referências bibliográficas}

AZEVEDO, Sérgio. "Desafios da Habitação Popular no Brasil: políticas recentes e tendências". In CARDOSO, A. L. (Org). Habitação Social nas Metrópoles Brasileiras. Uma avaliação das políticas habitacionais em Belém, Belo Horizonte, Porto Alegre, Recife, Rio de Janeiro e São Paulo no final do século XX. Porto Alegre: ANTAC, 2007. (Coleção HABITARE)

BARON, Cristina M. P.; ANELLI, Renato S. "Projeto de Urbanização em área subnormal - São Carlos - SP". In: Revista Tópos, v.3, n², Presidente Prudente, 2009, pp. 126-145.

BOLAFFI, Gabriel. "Habitação e urbanismo: o problema e o falso problema". In: MARICATO, E. (org.) A produção capitalista da casa (e da cidade) no Brasil industrial. São Paulo: Alfa-Omega, 1982

BONDUKI, Nabil. Origens da Habitação Social no Brasil. São Paulo: Estação Liberdade, 1998.

CARDOSO, Adauto Lúcio. Política habitacional no Brasil: balanço e perspectivas. IPPUR, UFRJ, s/d.

DEVESCOVI, Regina C. Balieiro. Urbanização e Acumulação. Um estudo sobre a cidade de São Carlos. São Carlos: Arquivo de História Contemporânea - UFSCar, 1987.

DOZENA, Alessandro. São Carlos e seu 'desenvolvimento': contradições urbanas de um pólo tecnológico. Dissertação (mestrado em Geografia). FFLCH - USP, São Paulo, 2001

FALKOSKI, Luiz Antonio Nigro. Metodologia de análise e avaliação do ambiente construído: desenho urbano $x$ infraestrutura. Dissertação (mestrado em Arquitetura). EESC - USP, São Carlos, 1988.

FELDMAN, Sarah. O Arranjo SERFHAU: assistência técnica aos municípios/órgãos de planejamento/empresas de engenharia consultiva. In: XI ENAMPUR, 2005, Salvador.

FERNANDES, Maria Esther (coord.). A Cidade e seus limites: as contradições do urbano na "Califórnia Brasileira". São Paulo: Annablume, FAPESP; Ribeirão Preto: UNAERP, 2004.

FERREIRA, Mauro. Planejamento urbano nos tempos do SERFHAU: o processo de construção e implementação do plano diretor de desenvolvimento integrado de Franca. Tese (doutorado em Arquitetura e Urbanismo), EESC-USP, São Carlos, 2007.

HECK, Eneida R. Beluzzo Godoy. A EMURB como ins trumento de planejamento urbano em São Paulo: 1971-2001. Dissertação (mestrado em Arquitetura e Urbanismo), FAU-USP, São Paulo, 2004.

LEME, Maria Cristina da Silva. A formação do pensamento urbanístico no Brasil: 1895-1965. In: LEME, Maria Cristina da Silva; FERNANDES, Ana; GOMES, Marco Aurelio F. (org.) Urbanismo no Brasil 1895-1965. São Paulo: Studio Nobel/FAU USP/FUPAM, 1999.

LIMA, Renata Priore. O processo e o (des)controle da expansão urbana de São Carlos (1857-1977). Dissertação (mestrado em Arquitetura e Urbanismo), EESC-USP, São Carlos, 2007. 
MELO, Marcus André B. C. de. Políticas públicas e habitação popular: continuidade e ruptura, 1979-1988. In: RUA. Salvador, 2 (2), p. 37-59, 1989

MONTE-MÓR, Roberto Luís de Melo. Do urbanismo à política urbana: notas sobre a experiência brasileira. In: Costa, Geraldo Magela; Mendonça, Jupira Gomes de. (orgs.). Planejamento Urbano no Brasil: trajetória, avanços e perspectivas. Belo Horizonte: C/Arte, 2008

MOTA, Juliana Cosa. Planos Diretores de Goiânia, década de 60: a inserção dos arquitetos Luís Saia e Jorge Wilheim no campo do planejamento urbano. Dissertação (mestrado em Arquitetura e Urbanismo), EESC-USP, São Carlos, 2005

PREFEITURA MUNICIPAL DE SÃO CARLOS (PMSC). Plano diretor do município de São Carlos. Levantamentos (CD-Rom). São Carlos, 2003.

PROHAB. Ontem: Favela do Gonzaga. Hoje: Jardim Gonzaga. Panfleto de divulgação da urbanização do Jardim Gonzaga. São Carlos, s/d. (mimeo)

TEIA - casa de criação. Plano Local de Habitação de Interesse Social de São Carlos. Relatórios (mimeo). São Carlos, 2010.

PULHEZ, Magaly Marques. Espaços de favela, fronteiras do ofício: história e experiências contemporâneas de arquitetos em assessorias de urbanização. Dissertação (mestrado em Arquitetura e Urbanismo), EESC-USP, São Carlos, 2007.

ROSA, Thaís Troncon. O Modelo entre a Alegoria e a Disputa: Reflexões sobre Práticas Participativas em Programas de Urbanização de Favelas. In: Simpósio Latino-Americano: Cidade e Cultura - Dimensões Contemporâneas (Anais). São Carlos, 2007

ROYER, Luciana de O. Financeirização da política habitacional: limites e perspectivas. Tese (doutorado em Arquitetura e Urbanismo), FAU-USP, São Paulo, 2009.

ROSA, Thaís Troncon. Fronteiras e Pontes: diálogos e disputas na produção do espaço urbano. O caso da consolidação da Favela do Gonzaga na periferia de São Carlos - SP. Memorial de Qualificação (Mestrado). IFCH-UNICAMP, Campinas (mimeo), 2007.

Fronteiras em disputa na producão do espaço urbano: a trajetória do 'Gonzaga' de favela a bairro de periferia. Dissertação (mestrado em História). IFCH - UNICAMP, Campinas, 2008.

SANTOS, Cláudio H. M. Políticas federais de habitação no Brasil: 1964/1998. Brasília: IPEA, 1999.

TEIA - casa de criação. Relatório geral urbanístico - Jardim Gonzaga e Vila Monte Carlo. Programa Habitar Brasil Bid/Prefeitura Municipal de São Carlos, São Carlos, 2002 